\title{
REPUBLIC OF AZERBAIJAN: SELECTED ISSUES
}




\section{INTERNATIONAL MONETARY FUND}

\section{REPUBLIC OF AZERBAIJAN}

\section{SELECTED ISSUES}

June 2014

This Selected Issues paper on the Republic of Azerbaijan was prepared by a staff team of the International Monetary Fund. It is based on the information available at the time it was completed on May 13, 2014.

Copies of this report are available to the public from

International Monetary Fund • Publication Services

PO Box 92780 - Washington, D.C. 20090

Telephone: (202) 623-7430 • Fax: (202) 623-7201

E-mail: publications@imf.org Web: http://www.imf.org

Price: $\$ 18.00$ per printed copy

International Monetary Fund

Washington, D.C. 


\title{
INTERNATIONAL MONETARY FUND
}

\section{REPUBLIC OF AZERBAIJAN}

SELECTED ISSUES

May 13, 2014

\author{
Approved By \\ Middle East and \\ Central Asia \\ Department
}

Prepared By S. Ben Naceur and B. Quillin

\section{CONTENTS}

DETERMINANTS OF BANK SPREADS IN AZERBAIJAN

3

A. Introduction__ $\underline{3}$

B. Methodology___ 4

C. Data and Variables __ $\underline{5}$

D. Empirical Results __ $\underline{8}$

E. Concluding Remarks __ $\underline{13}$

\section{FIGURE}

1. Financial Sector Indicators, 2002, 2007 and 2011

\section{TABLES}

1. Variables Definitions and Sources ___ $\underline{6}$

2. List of banks used in the sample __ $\underline{9}$

3. Summary Statistics and Correlations Tables__ 10

4. Determinants of Net Interest Spreads ___ 11

5. Economic Significance___ $\underline{13}$

REFERENCES

A. Assessing Financial Depth___ $\underline{18}$

B. Assessing the Relationship between Finance and Growth__ 24

C. Conclusion _ $\underline{28}$ 
FIGURES

1. Financial Reforms and Deepening, 2012 $\underline{20}$

2. Financial Sector Infrastructure, 2011 $\underline{21}$

3. Measures of Credit and Monetary Development, 2000-13 $\underline{25}$

\section{TABLES}

1. Determinants of Credit Growth Summary Statistics $\underline{23}$

2. Financial Development in Developing \& Emerging Market Economies 1990-2012 _ 23

3. Determinants of Real Non-hydrocarbon GDP Growth, 2003Q1-2012Q4 __ $\underline{26}$

4. Johansen Cointegration Test Results __ 27

5. VAR Model of Real Non-hydrocarbon GDP Growth, 2003Q1-2012Q4__ $\underline{28}$ 


\section{DETERMINANTS OF BANK SPREADS IN AZERBAIJAN ${ }^{1}$}

In this note, we use a bank-level panel dataset to investigate the determinants of bank interest spreads in Azerbaijan over the period 2002-13. We applied the dealership model of Ho and Saunders, supplemented by market structure and macroeconomic environment variables, to assess the extent to which high spreads of banks in Azerbaijan can be related to bank-specific variables or to a low degree of competition, controlling for macroeconomic factors. We find that interest spreads are affected by operation cost efficiency, credit risk, liquidity risk, bank size, bank diversification, banking sector competition, policy rate, and reserve requirement. The main implications of our results are that policies aimed at containing banks' interest margins should enhance bank efficiency, encourage greater competition, consolidate the small banks, and maintain a stable macroeconomic environment.

\section{A. Introduction}

1. Background: The net interest spread, measured as the difference between lending and borrowing rates, is widely regarded as an indicator of intermediation efficiency or cost of intermediation. In comparison to international standards, Azerbaijan has high banking spreads which may impede financial development: high lending rates discourage investment and low deposit rates reduce saving, hindering growth.

\section{Understanding why interest spreads in Azerbaijan are so high is, therefore, important for policymakers so they can take measures to lower intermediation costs and improve financial deepening. The persistence of high spreads may be a reflection of high operating costs, non-competitive market conditions, scale diseconomies, a high degree of information asymmetry, or an unstable macroeconomic environment.}

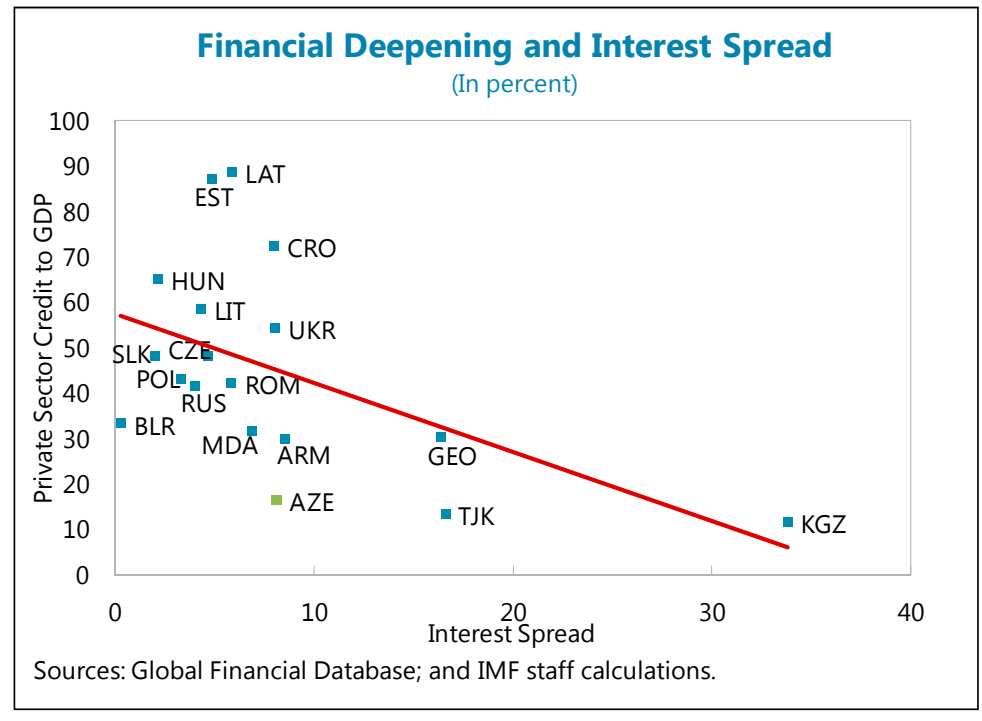

3. Objectives: This note investigates the factors behind the high interest spreads in Azerbaijan's banking sector over the period 2002-13. It makes several contributions to the literature

\footnotetext{
${ }^{1}$ Prepared by Sami Ben Naceur. The author thanks Mario Catalan (MCM) for detailed comments on an earlier draft and members of the IMF's Azerbaijan team.
} 
on interest spreads and margins. First, it contributes to a small literature on financial systems in the Caucasus and the Central Asia (CCA). Second, it utilizes a unique panel dataset comprising balance sheet and income statements of 20 banks observed over the period 2002-13. Third, it uses, in addition to a pooled OLS estimator, the fixed-effect panel estimator, to account for bank- specific effects, and the Arrelano and Bover (1995) system GMM estimator to solve the endogeneity problem and account for the persistence of the net interest spreads.

4. Key findings: Our results provide strong support for the importance of bank-specific factors (operating costs, bank size, bank liquidity, and diversification), market structure, and macroeconomic environment in explaining the interest rate variation in Azerbaijan. High operating costs, lack of competition, and diseconomies of scale for small banks remain key impediments that prevent interest spreads from declining in Azerbaijan.

5. The remainder of the note is organized as follows. Section B describes the methodology. Section $C$ specifies the data and variables. Section $D$ presents the empirical results. Finally, section $E$ contains concluding remarks as well as a number of policy implications.

\section{B. Methodology}

\section{Our empirical analysis will be based on the framework of the Ho and Saunders (1981)} model and its subsequent extensions. The most recent framework for the bank dealership model is given by Maudos and Fernandez de Guevara (2004) in which the theoretical motivated drivers of the net interest spread comprise operating costs, managerial risk aversion, credit risk, liquidity risk, interest rate risk, bank size, and market structure. Our model will supplement Maudos and Fernandez de Guevara by adding macroeconomic and regulation variables, and will be specified as follows:

$$
S P R E A D_{i, t}=\alpha+\beta \mathrm{BSV}_{i, t}+\gamma \mathrm{MS}_{t}+\delta \mathrm{ME}_{t}+\mu_{i}+v_{i, t}
$$

where $i$ and $t$ stand for bank $i$ at time t. SPREAD is the bank's interest spread, BSV, is a vector of theoretically motivated determinants of bank spread, while MS and ME are vectors of market structure and macroeconomic variables respectively, $\mu_{i}$ is a bank-specific error term to capture individual bank heterogeneity and $v_{i, t}$ is an i.i.d random error.

\section{Three different empirical approaches have been used to estimate the above model: (i)}

the first method uses a two-step procedure, in which the first step, cross-sectional regressions of net interest spreads of individual banks, is performed in each country for each period; in the second step, the time series of pure interest spread is regressed on a set of market structure and interest volatility. This approach is only feasible with a long time series and a large cross-section of observations (see Brock and Suarez, 2000; Agbanzo, 1997; Saunders and Schumacher, 2000); (ii) the second method uses a single-step procedure that includes all the theoretical and other determinants of the net interest spreads. This approach has used pooled OLS, pooled WLS, and GLS estimators (Kasman, 2010; Claeys and Vander Vennet, 2008; Maudos and Fernandez de Guevara, 2004); and (iii) the third method uses a single-step procedure like the second method, but 
it accounts for the persistence of net interest spreads over time and controls for endogeneity. In terms of estimation technique, this approach uses a GMM estimator (Maudos and Solis, 2008, Horvath, 2009; Garcia-Herrero, Gravity, and Santa Barbara, 2009; and Dietrich and Wanzenried, 2011). As our data set covers only 10 years, we will use only the second and third approach.

\section{In addition to using pooled OLS with robust errors to estimate the coefficient in our}

models, equation 1 is estimated with panel data estimators to capture the impact of specific variables of each bank. A Fisher test is used to determine whether our data require panel data estimation or pooled OLS. Panel data models are estimated using either the fixed-effects or random-effects estimators. A Hausman test is used to determine whether a fixed-effect (least-square Dummy Variables) or random-effect estimator is appropriate.

\section{Data and Variables}

9. The sample is formed of an unbalanced panel of data from $\mathbf{1 0 5}$ annual observations, corresponding to 20 commercial and savings banks for the period between 2002 and 2013. Banklevel data in the sample were taken from the Bankscope database, the data on macroeconomics were obtained from the IMF's International Financial Statistics, and data on market structure form the World Bank's Global Financial Development Database (GFDD). Table 1 describes the variable definitions, as well as data sources and expected relationship with bank spreads

10. We use as a dependent variable the bank's interest spread, defined as the difference between the lending rate and borrowing rate, which measures also the cost of financial intermediation. The lending rate is computed as the ratio "Interest Income on Loans / Average Gross Loans" and the borrowing rate is calculated as the ratio of Interest Expense / Average Interestbearing Liabilities." 


\begin{tabular}{|c|c|c|c|}
\hline Variables & Definition & Source & Expected Sign \\
\hline $\begin{array}{l}\text { Net interest spread } \\
\text { (SPREAD) }\end{array}$ & $\begin{array}{l}\text { The difference between interest } \\
\text { incomes divided by total loans } \\
\text { and interest expenses divided by } \\
\text { total deposits and borrowings }\end{array}$ & Bankscope & Dependent \\
\hline $\begin{array}{l}\text { Operational efficiency } \\
\text { (OC) }\end{array}$ & $\begin{array}{l}\text { Ratio of operating costs to total } \\
\text { assets }\end{array}$ & Bankscope & + \\
\hline $\begin{array}{l}\text { Risk aversion } \\
\text { (CAP) }\end{array}$ & Ratio of total equity to total assets & Bankscope & $?$ \\
\hline $\begin{array}{l}\text { Credit risk } \\
\text { (CRISK) }\end{array}$ & $\begin{array}{l}\text { Ratio of loan loss provisions to } \\
\text { total loans }\end{array}$ & Bankscope & + \\
\hline $\begin{array}{l}\text { Size of operations } \\
\text { (SIZE) }\end{array}$ & Logarithm of total loans & Bankscope & + \\
\hline $\begin{array}{l}\text { Bank diversification } \\
\text { (NII) }\end{array}$ & $\begin{array}{l}\text { Non-interest revenues / Total } \\
\text { assets }\end{array}$ & Bankscope & - \\
\hline $\begin{array}{l}\text { Liquidity risk } \\
\text { (LRISK) }\end{array}$ & $\begin{array}{l}\text { Ratio of liquid assets to deposits } \\
\text { and short term funding. }\end{array}$ & Bnakscope & + \\
\hline $\begin{array}{l}\text { Inflation } \\
\text { (CPI) }\end{array}$ & $\begin{array}{l}\text { Annual rate change in the } \\
\text { consumer price index }\end{array}$ & $\begin{array}{l}\text { IMF International } \\
\text { Financial Statistics } \\
\text { Database }\end{array}$ & + \\
\hline $\begin{array}{l}\text { Interest rate risk } \\
\text { (MRISK) }\end{array}$ & $\begin{array}{l}\text { Standard deviation of monthly } \\
\text { treasury bills rates }\end{array}$ & $\begin{array}{l}\text { IMF International } \\
\text { Financial Statistics } \\
\text { Database }\end{array}$ & + \\
\hline $\begin{array}{l}\text { Interest rate } \\
\text { (POLICY) }\end{array}$ & Central bank refinancing rate & $\begin{array}{l}\text { National Bank of } \\
\text { Azerbaijan }\end{array}$ & + \\
\hline $\begin{array}{l}\text { Opportunity costs of bank reserves } \\
\text { (OCR) }\end{array}$ & $\begin{array}{l}\text { Ratio of liquid reserves to total } \\
\text { assets }\end{array}$ & Bankscope & $?$ \\
\hline $\begin{array}{l}\text { Lerner index } \\
\text { (LERNER) }\end{array}$ & $\begin{array}{l}\text { The difference between total } \\
\text { revenue and total cost divided by } \\
\text { the total revenue as proxy for } \\
\text { market power }\end{array}$ & $\begin{array}{l}\text { World Bank's financial } \\
\text { structure database }\end{array}$ & + \\
\hline
\end{tabular}

11. Based on the theory of the determinants of bank interest spreads (see Maudos and Fernandez de Guevara (2004), who provide the most recent framework for the bank dealership model), the bank-specific variables considered in our estimation are as follows: 
- Operation efficiency $(\mathbf{O C})$ proxies for the cost of servicing and monitoring transactions, among others, and is measured by the ratio of operating expenses to total assets. Less efficient banks, experiencing larger operating costs, tend to require higher spreads. A positive coefficient on this variable is expected.

- Degree of management risk aversion (CAP) is proxied by the equity-to-total assets ratio. A higher ratio indicates higher risk aversion by bank managers. The expected sign on this variable is ambiguous: on the one hand, highly capitalized banks are more solvent, which will reduce their funding costs and, therefore, strengthen their spreads; on the other hand, higher risk aversion may encourage banks to invest their resources in less risky assets, producing lower spreads (Poghosyan, 2012).

- Credit risk (CRISK) is defined by the ratio of loan loss provisions to gross loans. A higher ratio is associated with lower credit quality and high credit risk. Banks are expected to require higher interest spreads to compensate for funding riskier projects, and to maintain adequate loan reserves (Poghosyan, 2012).

- $\quad$ Liquidity risk (LRISK) is measured by the ratio of liquid assets to deposits and short-term funding. This ratio captures the impact of holding low-yielding assets on the bank's interest spread. A positive relationship between the liquidity risk and bank spreads is expected because banks will require compensation for holding low-return liquid assets (Brock and Suarez, 2000; and Poghosyan, 2012).

- $\quad$ Size of operation (SIZE) is proxied by the logarithm of loans. The theoretical literature does not provide an unequivocal answer on the relationship of the volume of loans and the interest spread. On the one hand, larger transactions spread operating costs on a larger base, which enables large banks to achieve lower interest margins by virtue of economies of scale. On the other hand, the larger the operation, the larger the potential loss will be, resulting in a positive relationship between the volume of loans and net interest spreads.

- Bank diversification (NII) is measured by the ratio of non-interest income to total assets. A diversified bank is expected to offer its interest-dealing activities with lower spreads, to attract new customers and compensate these opportunity costs by higher fees and commissions (see Petit and others, 2007, for cross-subsidization strategy); hence, a negative sign is expected.

\section{Market structure is measured by market power (LERNER) instead of the concentration}

ratio, because the former cannot provide a satisfactory measure of the degree of market competition in the banking sector (see Beck and Hess, 2009). Market power is proxied by the Lerner index which is the difference between the price and the total marginal costs (operating + financial) 
as a proportion of the price. ${ }^{2} \mathrm{~A}$ lower Lerner index indicates a strong degree of competition in the banking sector, which results in lower spreads ${ }^{3}$. Therefore, a positive relationship between the Lerner index and the interest spreads is suggested; banks with greater market power can fix higher spreads than they could in a more competitive market.

\section{Among macroeconomic factors, inflation (CPI), interest rate risk (MRISK), the} opportunity cost of reserves (OCR) and the policy rate (POLICY) are included. The CPI variable is calculated as the year-end change in CPI, and, in general, is expected to have a positive relationship with net interest spreads (see Boyd and others, 2001; and Gelos, 2006) because higher inflation introduces economic uncertainty that needs to be compensated by higher spreads (Poghosyan, 2012). MRISK is proxied by the standard deviation of the monthly series of treasury bills rates. Interest rate risk measures market risk and it is expected to increase bank interest spreads (Ho and Saunders, 1981; and Saunders and Schumacher, 2000, among others). OCR is used to capture the regulatory costs, and is proxied by the ratio of cash plus balances with central banks to total assets. The opportunity cost corresponds to the additional interest rate that banks can obtain by investing reserves in the financial market. A positive correlation with the interest spread is expected because the larger the amount of reserves at the central bank, the greater the opportunity cost, and the higher the spreads needed to compensate the missing interest. POLICY is the refinancing rate at the central bank, and it controls for monetary policy.

\section{Empirical Results}

\section{Table $\mathbf{3}$ provides descriptive statistics and the correlation matrix of interest spreads} and their determinants. The statistics indicates that SPREAD is on average around 9.5 percent during the period 2002-13, and is much larger than the average of developing and high-income economies. The LERNER index shows that competition in Azerbaijan has been improving since 2007; but it is still below the average for high-income economies. Operating costs are on average 5.1 percent of the value of assets, much higher than the average in developing and developed economies, but the gap is shrinking. Finally, inflation on average has been around 5.2 percent during the period but it has been very volatile. The sign of the bilateral coefficients of correlation between SPREAD and the explanatory variables are in accordance with expectations except for the variable CRISK where it is negative. The bank-specific variables are the ones with the highest correlation with the spread. The high correlation of POLICY and CPI with LRISK and OCR is an argument against including them in the same regressions to avoid multi-colinearity.

\footnotetext{
${ }^{2}$ The price is proxied by total revenues, and the marginal cost is estimated from a translog total cost function (see Maudos and Solis, 2009 for more details on the methodology).

${ }^{3}$ The value of the Lerner index ranges from 0 (perfect competition) to 1 (monopoly).
} 
Table 2. List of banks used in the sample

AtaBank OJSC

Azerigazbank Joint-Stock Investment Bank-AGBANK

Azer-Turk Bank Open Joint-Stock Company

Bank Eurasia OJSC

Bank of Azerbaijan

Bank Standard CJSC

Bank Technique OJSC

Demirbank Open Joint Stock Company

'Expressbank' Open Joint Stock Company

Investment Commercial Bank Nikoil OJSC

Kapital Bank

KredoBank OJSC

'Muganbank' Open Joint Stock Company

OJSCB Bank of Baku

Open Joint Stock Company Bank Respublika

Parabank OJSC

PASHA Bank OJSC

Rabitabank Open-Joint Stock Company

The Open Joint Stock Company "International Bank of Azerbaijan-OJSC "IBA

TuranBank Open Joint Stock Company

UniBank Commercial Bank

United Credit Bank

Xalq Bank OJSC

YapiKredi Bank Azerbaijan 


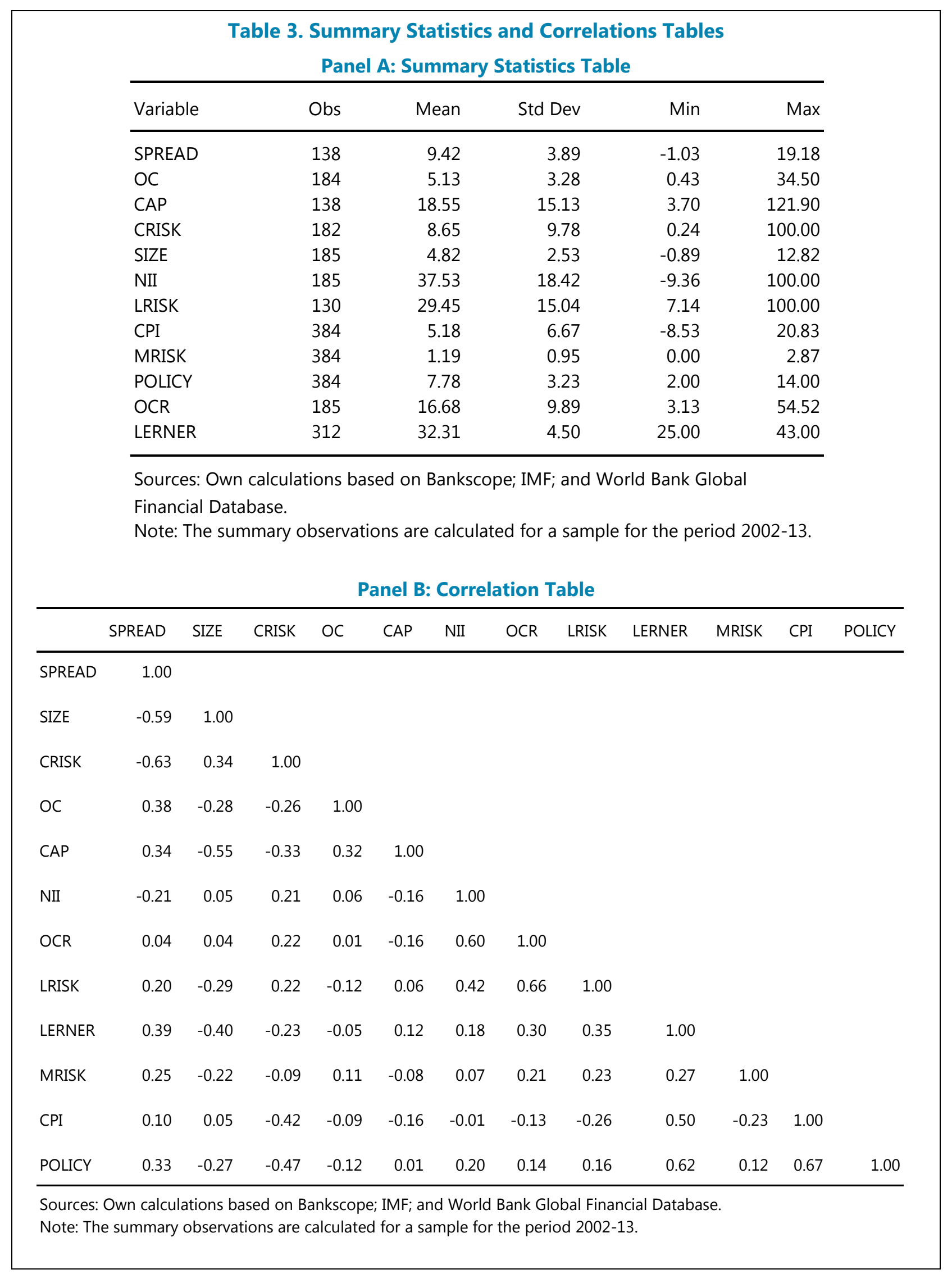




\section{Table 4 presents estimation results of fixed effects (columns 1, $\mathbf{3}$ and 5) and random} effects (columns 2, 4 and 6). Table 4 summarizes the economic impact of the explanatory variables on the interest spread, to compare the importance of the coefficients. Generally speaking, not only are most of the coefficients strongly significant with the expected sign, but the results are consistent across estimation models.

\section{As indicated in Table 4, the $\mathbf{F}$ test is significant and confirms the presence of firm-} specific effects. The Hausman test indicates that the fixed-effect model is the more appropriate with the baseline specification, while the random-effect model is more appropriate when market and macroeconomic variables are included.

\begin{tabular}{|c|c|c|c|c|c|c|c|c|c|c|c|c|c|}
\hline \multirow{2}{*}{$\begin{array}{l}\text { Regressors } \\
\text { OC }\end{array}$} & \multicolumn{2}{|c|}{ FEM } & \multicolumn{2}{|r|}{ REM } & \multicolumn{3}{|c|}{ FEM } & \multicolumn{2}{|c|}{ REM } & \multicolumn{2}{|c|}{ FEM } & \multicolumn{2}{|c|}{ REM } \\
\hline & $0.47^{* *}$ & * $(0.18)$ & 0.59 * & 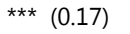 & 0.51 & ** & $(0.24)$ & 0.64 & 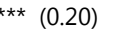 & $0.55 * *$ & $(0.24)$ & 0.68 * & ** $(0.20)$ \\
\hline CAP & -0.04 & $(0.04)$ & -0.03 & $(0.04)$ & 0.00 & & $(0.03)$ & 0.01 & $(0.02)$ & 0.00 & $(0.02)$ & 0.01 & $(0.02)$ \\
\hline CRISK & $-0.43 * *$ & $* *(0.05)$ & $-0.47 *$ & $* \star * \quad(0.05)$ & -0.40 & *** & $(0.09)$ & -0.41 & $* * * \quad(0.08)$ & $-0.26 * *$ & $(0.10)$ & $-0.29 *$ & ** $(0.09)$ \\
\hline SIZE & -1.59 ** & * $(0.29)$ & $-0.71 *$ & $\star \star \star *(0.19)$ & & & & & & & & & \\
\hline NII & -0.06 ** & $* *(0.02)$ & -0.06 * & *** $(0.02)$ & -0.03 & & $(0.02)$ & -0.04 & $(0.02)$ & -0.04 & $(0.02)$ & -0.04 * & $*(0.02)$ \\
\hline LRISK & 0.02 & $(0.03)$ & 0.08 * & 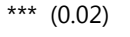 & & & & & & & & & \\
\hline OCR & & & & & 0.07 * & ** & $(0.03)$ & 0.06 & ** $(0.03)$ & $0.08 * *$ & $(0.03)$ & 0.08 * & ** $(0.03)$ \\
\hline LERNER & & & & & 0.41 & *** & $(0.11)$ & 0.42 & $\star \star * * \quad(0.10)$ & $0.26^{* * *}$ & $(0.08)$ & 0.25 * & ** $(0.08)$ \\
\hline MRISK & & & & & -0.13 & & $(0.28)$ & -0.16 & $(0.28)$ & 0.15 & $(0.22)$ & 0.11 & $(0.22)$ \\
\hline CPI & & & & & -0.05 & & $(0.05)$ & -0.06 & $(0.05)$ & & & & \\
\hline POLICY & & & & & & & & & & 0.16 * & $(0.08)$ & 0.15 * & $(0.08)$ \\
\hline Cons & 21.59 ** & $*(2.63)$ & 14.20 * & *** $(1.98)$ & -1.29 & & (2.58) & -2.16 & (2.52) & 0.16 & $(2.40)$ & -0.18 & (2.34) \\
\hline R2: Within & 0. & 77 & & 0.74 & & 0.61 & & & 0.60 & 0.63 & & & 62 \\
\hline Between & 0. & 34 & & 0.52 & & 0.37 & & & .43 & 0.37 & & & 43 \\
\hline Overall & 0. & 59 & & 0.70 & & 0.51 & & & .55 & 0.49 & & & 54 \\
\hline $\mathrm{F}$ test (p-value) & 0. & 00 & & & & 0.00 & & & & 0.00 & & & \\
\hline Wald test ( $p$-value) & & & & 0.00 & & & & & 0.00 & & & & 00 \\
\hline Hausman's test ( $p$-value) & & & 0 & & & & & & & & & & \\
\hline Observations & 9 & 1 & & 91 & & 88 & & & 88 & 88 & & & 38 \\
\hline
\end{tabular}

\section{We first consider the bank-specific determinants of net interest spreads. The} coefficients of the operating expenses variable are significant and positive in all estimations, indicating that banks with high operating expenses (less efficient) have to be compensated by higher spreads. The result suggests that more efficient banks pass lower administrative costs on to their customers through higher deposit or lower lending rates (Claeys and Vander Vennet, 2008; and Horvath, 2009). This result is consistent with that obtained by Maudos and Fernandez de Guevara (2004) for European banks, Williams (2007) for Australian banks, Horvath (2009) for Czech Banks, Mados and Solis (2009) for Mexico, and Gelos (2006) for Latin American banks.

\section{Higher spreads are associated with smaller bank sizes, because the coefficients on} bank size are all negative and significant. This finding is consistent with theories emphasizing economies of scale in intermediation costs; but they contradict the supposition that large banks may impose their market power by raising margins (Horvath, 2009). This result is in line with Horvath 
(2009) for Czech Banks, Gelos (2006) for Latin American banks, Maudos and Fernandez de Guevara (2004) for European banks and Fungacova and Poghosyan (2011) for Russian banks; but it contrasts with Claeys and Vander Vennet (2008) and Schwaiger and Liebig (2008), who find no relationship in new EU member banks and Central and Eastern European banks, respectively.

19. While a positive correlation was expected between the net interest spread and credit risk, this correlation resulted negative and significant, confirming the findings of Fungacova and Poghosyan (2011) for Russian banks, Gunter and others (2013) for Austrian banks, William (2007) for Australian banks, and Guiso and others (2006). These findings could be attributed to mispricing of risk, because higher levels of provisions for nonperforming loans (NPLs) would not be fully compensated for by net interest spreads (DeYoung and Nolle, 1996; and Williams, 2007). Moreover, inadequate accounting standards and inappropriate classification of loan loss provisions in Azerbaijan make the concept of credit risk irrelevant.

\section{Consistent with the opportunity costs hypothesis, the liquidity ratio is positively and} significantly correlated with the spreads for most of the regressions, and is in line with Ghosh (2008) for India, Poghosyan (2010) for Central and Eastern European countries, and Poghosyan (2013) for a large sample of emerging and low-income economies. This result reflects the compensation required by banks in the form of higher spreads to hold liquid assets.

\section{The non-interest income variable has a significant negative coefficient for all the} regressions, suggesting cross-subsidization of fee- and commission-generating activities with traditional lending activities (Carbo and Rodriguez 2007; and Le Petit and others, 2008). More diversified banks charge lower spreads for loans to gain a higher income from non-interest activities, because they consider the two sources of income as substitutes for each other (Kalluci, 2010).

\section{Table $\mathbf{4}$ also reports results for interest spreads, including market structure and} macroeconomic variables. With respect to the market structure variables, the Lerner index has the expected positive and significant sign, in accordance with Liebig and Schawaiger (2006), Maudos and Solis (2009), or Entrop and others (2012). This result reveals that banks with monopoly power can charge higher lending rates and offer lower deposit rates. The results also reveal that macroeconomic conditions affect spreads, too: policy rate is positive and significant in all our models, which suggests that stable prices combined with low policy rates are essential for reducing interest spreads. The reserve requirement is another monetary or regulatory policy tool that could affect the cost of intermediation; its proxy, the opportunity cost of bank reserves variable, is positively and significantly associated with spreads in all of the regressions. This result is consistent with Brock and Suarez (2000) and Saunders and Schumacher (2000), who argue that higher reserve requirements are translated into higher interest spreads to compensate for the missing incomes resulting from zero or low return on reserves.

\section{Table $\mathbf{5}$ shows the economic significance instead of the statistical coefficients for each} variable in all specifications using standardized variables. The advantage of this approach over statistical significance is that we use comparable coefficients. The results indicate the comparatively large impact of bank size, operating costs, and non-interest revenues on banks' spreads. The high 
and negative coefficients on credit risk confirm the absence of risk-adjusted pricing process in Azerbaijan.

\begin{tabular}{|c|c|c|c|c|}
\hline \multicolumn{5}{|c|}{ Table 5. Economic Significance ${ }^{4}$} \\
\hline Regressors & FEM & REM & REM & Average \\
\hline OC & 0.3920 & 0.5407 & 0.5725 & 0.5018 \\
\hline CAP & -0.0150 & 0.0424 & 0.0528 & 0.0267 \\
\hline CRISK & -1.0776 & -1.0360 & -0.7211 & -0.9449 \\
\hline SIZE & -1.0291 & & & -1.0291 \\
\hline NII & -0.2901 & -0.1709 & -0.1971 & -0.2194 \\
\hline LRISK & 0.0680 & & & 0.0680 \\
\hline OCR & & 0.1582 & 0.1959 & 0.1771 \\
\hline LERNER & & 0.4836 & 0.2931 & 0.3884 \\
\hline MRISK & & -0.0381 & 0.0270 & -0.0055 \\
\hline CPI & & -0.1009 & & -0.1009 \\
\hline POLICY & & & 0.1255 & 0.1255 \\
\hline
\end{tabular}

\section{E. Concluding Remarks}

24. Summary: The results show that operational efficiency is a very important driver of interest spreads in Azerbaijan. Higher operating costs are reflected in higher interest spreads. Size also turns out to be an important determinant of bank spreads, and we interpret this finding as evidence of the existence of room for consolidating the Azeri banking sector. We find also that banks under study are not able to exploit concentration in the market to increase their spreads; however, intensified competition in the banking sector has acted to reduce interest spreads. Our results show that banks that rely heavily on fee-based activities have lower lending rates that underprice credit risk (crosssubsidization may distort risk exposures) and could raise issues for bank regulation and competition with non-bank lenders (See Petit and others, 2008). Another interesting result is that capital adequacy is not a statistically significant explanatory variable for the bank spread. This result may reflect the fact that capital in Azerbaijan is fictitious, calling into question the value of assets and collateral and the provisioning of NPLs. In the same vein, a negative correlation between credit risk and spread reflects inadequate interest spreads (mispricing of risks) to compensate for provisions for NPLs. Aside from the bank-specific and market structure variables, the macroeconomic environment-approximated by the policy rate, and the reserve requirement-has a significant

\footnotetext{
${ }^{4}$ The economic significance coefficients are obtained by using standardized variables $z=(x-\mu) / \sigma$ where $\mu$ is the mean of the population; and $\sigma$ is the standard deviation of the population.
} 
impact on interest spread. More specifically, a stable macroeconomic environment with low inflation, low interest rate, and low reserve requirement will support lower net interest spreads.

25. Policies: The analysis suggests that it is important to reduce operating costs, to increase competition, to consolidate the small bank segments, and to maintain a stable macroeconomic environment to lower bank interest margins. Specifically, reducing operating costs could be achieved by enhancing banking sector competition and consolidation; adopting the best banking technologies such as mobile banking, internet banking, ATMs, to reduce the need for a large branch network; improving staff training and management practices; strengthening bank corporate governance; introducing organizational changes (such as outsourcing). Enhancing competition in the banking sector could be achieved by downsizing of the International Bank of Azerbaijan (IBA) either through sale of assets or by splitting into areas of business; the promotion of non-banking financial institutions and capital markets; the reduction of loan concentration through stricter supervision of large exposures; the improvement of transparency and disclosure of bank products and services; and the reform of legislation and regulation related to bank resolution activities in order to facilitate the exit of weaker banks. As small banks in Azerbaijan are operating with significant unrealized economies of scale, the authorities could allow for market-led consolidation of smaller banks, which will contribute to greater cost efficiency and lower interest rate spreads. As the increase of the minimum capital from AZN 10 millions to AZN 50 millions has not yet contributed to consolidating the banking sector, the authorities should allow small nonperforming banks to exit the market; convert undercapitalized banks into non-bank financial institutions (NBFIs); and encourage the healthier banks to merge with or acquire weaker banks by ensuring that bureaucratic and procedural formalities are minimal; allowing debt-to-equity swaps; and offering incentives to the banks such as lowering the deposit insurance premium, decreasing the reserve requirements, or proving tax advantages. Promoting a stable macroeconomic environment (low and stable inflation) should contribute to lower equilibrium interest rates; lowering reserve requirements is likely to reduce the cost of intermediation. Because credit risks are underestimated and capital nonsignificant in explaining interest rate spreads, there is a need to strengthen the identification of NPLS and loan loss provision implementation rules, to improve risk management techniques, and to address deficiencies in supervisory practices. 


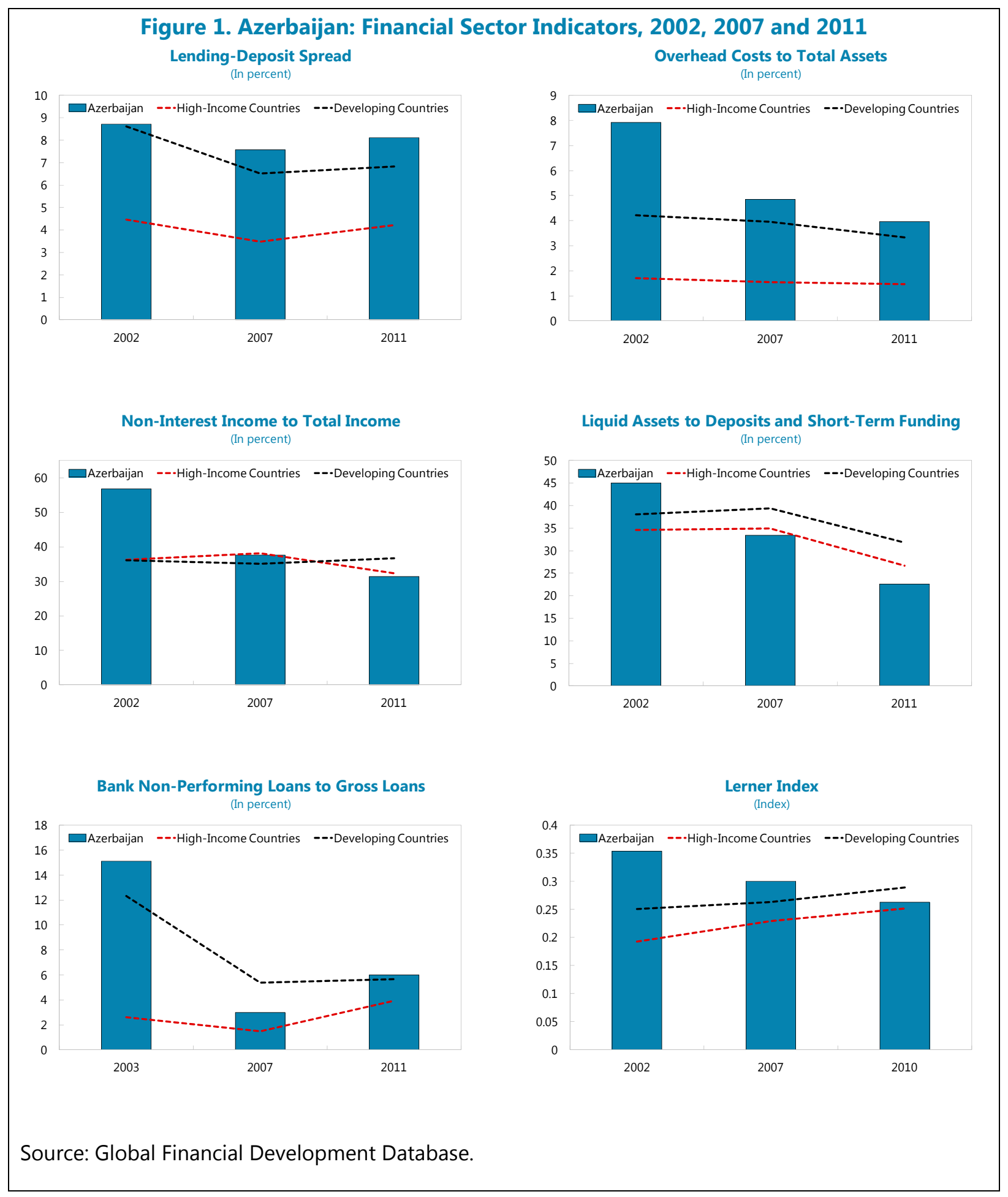




\section{References}

Angbazo, L., 1997. "Commercial Bank Net Interest Margins, default risk, interest rate risk and off balance sheet banking." Journal of Banking and Finance 21, pp. 55-87.

Arellano, M., O. Bover, 1995. "Another look at the instrumental-variable estimation of errorcomponents models." Journal of Econometrics Vol. 68 (1), pp. 29-51.

Beck, T., and H. Hess, 2009, "Why Are Interest Spreads So High in Uganda?" Journal of Development Economics, Vol. 88, pp. 192-204.

Blundell, R.W., and S. R. Bond, 1998. "Initial conditions and moment restrictions in dynamic panel data models." Journal of Econometrics Vol. 87, pp. 115-143.

Boyd, J., R., Levine, and B. Smith, 2001. "Inflation and financial market performance." Journal of Monetary Economics Vol. 47 (2), 221-248.

Brock, P.L., and L. Rojas, 2000. Understanding the behavior of bank spreads in Latin America. Journal of Development Economics Vol. 63, pp. 113-134.

Carbó, S., F. Rodriguez, 2007. The determinants of banks' margins in European banking. Journal of Banking and Finance Vol. 31, pp. 2043-2063.

Claeys, S., R. Vander Vennet, 2008. "Determinants of bank interest margins in Central and Eastern Europe: a comparison with the West." Economic Systems Vol. 32, pp. 197-216.

Dabla-Norris, E. and Floerkemeier, H. (2007). Bank Efficiency and Market Structure: What Determines Banking Spreads in Armenia? IMF Working Paper No. 07/134 (Washington: International Monetary Fund).

DeYoung, Robert, and Daniel E. Nolle, 1996, "Foreign-owned banks in the United States: earning market share or buying it," Journal of Money, Credit and Banking Vol. 28, pp. 622-636.

Dietrich, A., and G. Wanzenried, 2011, "Determinants of bank profitability before and during the crisis: evidence from Switzerland," Journal of International Financial Markets, Institutions and Money, Vol. 21, pp. 307-327.

Entrop, O., C. Memmel, B. Ruprecht, and M. Wilkens, 2012. "Determinants of bank interest margins: Impact of maturity transformation." Working Paper. Deutsche Bundesbank Discussion Paper Series 2: Banking and Financial Studies No 17/2012 (Frankfurt am Main).

Fungáčová, Zuzana \& Poghosyan, Tigran, 2011. "Determinants of bank interest margins in Russia: Does bank ownership matter?,"Economic Systems, Elsevier, vol. 35(4), pages 481-495. 
Garcia-Herrero, A., S. Gavila, and D. Santabarbara, 2006. "China's banking reform: an assessment of its evolution and possible impact", CESifo Economic Studies, Vol. 52, pp. 304-363.

Gelos, R., 2006. Banking Spreads in Latin America. IMF Working Paper WP/06/44, (Washington: International Money Fund).

Ghosh, S., 2008, "Regulatory Pressure, Market Discipline and Bank Spreads in India: An Empirical Exploration," Global Economic Review, Vol. 37(2): pp. 227-47.

Guiso, L., S. Paola, and L. Zingales, 2006. "The Cost of Banking Regulation," NBER Working Paper 12501 (Cambridge, MA: National Bureau for Economic Research).

Gunter, U., G. Krenn, and M. Sigmund, 2013. "Macroeconomic, market and bank-specific determinants of the net interest margin in Austria," Financial Stability Report 25. OeNB, pp. 87-101 (Vienna: National Bank of Austria).

Hanweck, G., and L. Ryu, 2005. The Sensitivity of Bank Net Interest Margins and Profitability to Credit, Interest-Rate, and Term-Structure Shocks Across Bank Product Specializations, Working Paper 2005-02, Federal Deposit Insurance Corporation (Washington).

Ho, T.S., and A. Saunders, 1981, "The determinants of bank interest margins: theory and empirical evidence." Journal of Financial Quantitative Analysis Vol. 16, pp. 581-600.

Horvath, R., 2009. "Interest Margins Determinants of Czech Banks." Institute of Economic Studies, Faculty of Social Sciences, Charles University, WP 11/09 (Prague).

Kalluci, I. (2010), "Determinants of Net Interest Margin in the Albanian Banking System," Working Paper Series, April, Bank of Albania (Tirana).

Kasman, A., 2010. "Consolidation and Commercial bank net interest margins: evidence from the old and new European union members and candidate countries." Economic Modeling Vol. 27, pp. 648-655.

Lepetit, L., E. Nys, P. Rous, A. Tarazi, 2008. "The expansion of services in European banking: implications for loan pricing and interest margins." Journal of Banking and Finance Vol. 32, pp. 2325-2335.

Soto, M. 2009. "System GMM estimation with a small sample,"Working Papers 395, Barcelona Graduate School of Economics. 


\section{ASSESSING FINANCIAL DEVELOPMENT IN AZERBAIJAN ${ }^{1}$}

\section{A. Assessing Financial Depth}

1. Financial development is important for broad-based economic growth. A large and growing body of empirical research has found that a prudentially sound and well developed financial system is an important contributor to macroeconomic growth generally and private sector development in particular. ${ }^{2}$ Using a variety of methodologies across a range of countries, the literature finds that financial development allows households and firms to better manage risks and volatility and supports the efficient allocation of savings to support business creation and investment. ${ }^{3}$ Some research has found that financial development particularly benefits SME creation and performance. ${ }^{4} \mathrm{~A}$ well developed financial system also enhances the effectiveness of macroeconomic management by improving the transmission of monetary policy, increasing fiscal space, and permitting a wider choice of exchange rate regime. ${ }^{5}$

\section{The deepening of financial systems is particularly important for natural resource} exporting economies. Robust financial systems can support economic diversification by promoting private sector development. Moreover, the relationship between financial depth and diversification can be reinforcing so that increased diversification can further support financial development. ${ }^{6}$

\section{Financial sector development and intermediation in Azerbaijan lags other transition} economies. Like other post-Soviet transition economies, Azerbaijan had to dismantle the one-tier centralized banking system and begin building a deeper and more modern financial system only 20 year ago. ${ }^{7}$ The country was successful in establishing a core supervisory framework, enacting

\footnotetext{
${ }^{1}$ Prepared by Bryce Quillin. The author thanks Adolfo Barajas for detailed comments on an earlier draft and members of the IMF's Azerbaijan team.

2 Levine, R. and S. Zervos, 1998, "Stock Markets, Banks, and Economic Growth," American Economic Review, 88, 537558. Levine, R., 2003, "More on Finance and Growth: More Finance, More Growth?" Federal Reserve Bank of St. Louis Review, 85(4), 2003, 31-46.

${ }^{3}$ Aghion, P., T. Fally, and S. Scarpetta, 2007, "Credit Constraints as a Barrier to the Entry and Post-Entry of Firms, Economic Policy, 22, 731-779. Ayyagari, M., A. Demirguc-Kunt, and V. Maksimovic, 2011, "Firm Innovation in Emerging Markets: The Role of Finance, Governance, and Competition," Journal of Financial and Quantitative Analysis, 46, 1545-80.

${ }^{4}$ Beck, T. "Finance and growth-lessons from the literature and recent crisis."

${ }^{5}$ Ibid.

${ }^{6}$ Ramcharan, R. 2006, "Does Economic Diversification Lead to Financial Development? Evidence from Topograhy," IMF Working Paper WP/06/35.

7 IMF, Forthcoming, "The Caucuses and Central Asia: Transitioning to Emerging Economies".
} 
modern retail payment systems, implementing mandatory International Financial Reporting Standards, and implementing AML/CFT legislation. Yet, intermediation remains limited and Azerbaijan lags most other transition economies on credit to the private sector and the level of deposits, including economies with much lower levels of GDP per capita (Fig 1). Banking sector assets, as a percentage of GDP, and foreign ownership of the banking sector are the lowest among transition economies. Part of the low level of financial development may be explained by limited amounts of policy reform. Cross-country comparisons assembled by the EBRD show that Azerbaijan may be on par with other economies in Central Asia and the Caucasus in financial development, yet they lag other transition economies in Central and Eastern Europe and Russia by large margins.

4. Financial sector access also appears to be undeveloped. Less than 20 percent of the population has an account with a formal financial institution, which is among the lowest in the region and below levels recorded in some countries with lower per capital incomes (Fig 2). The penetration of savings accounts and mortgage loans is also low. The limited level of participation in the formal financial system may partly explain why lending from friends and family is an important source of credit.

\section{Cross-country analyses suggest that resource rich economies often have lower levels} of financial development, perhaps due to weaker financial and business climate policies and institutions. Previous research has found that oil exporters tend to have lower levels of financial development and the impact of the financial sector on growth tends to be weaker. ${ }^{8}$ In particular, one paper noted that oil exporters tend to have smaller financial sectors than non-oil exporters at similar levels of per capita income, reflecting: (i) the outcome that oil exports can increase GDP without increases in economic and financial activity; and (ii) the reliance on international trade in oil exporters enhances international financial activity at the expense of domestic financial intermediation. ${ }^{9}$

\footnotetext{
${ }^{8}$ See Barajas, A., R. Chami, and S.R. Yousefi, 2013, "The Finance and Growth Nexus Re-Examined: Do All Countries Benefit Equally?," IMF Working Paper 13/130.

9 Beck, T., E.H.B. Feyen, and F. Moizeszowicz, 2008, "Benchmarking Financial Development," Policy Research Working Paper No. 4638, World Bank.
} 
Figure 1. Financial Reform and Deepening, 2012 1/

State of Financial Sector Reform 2/
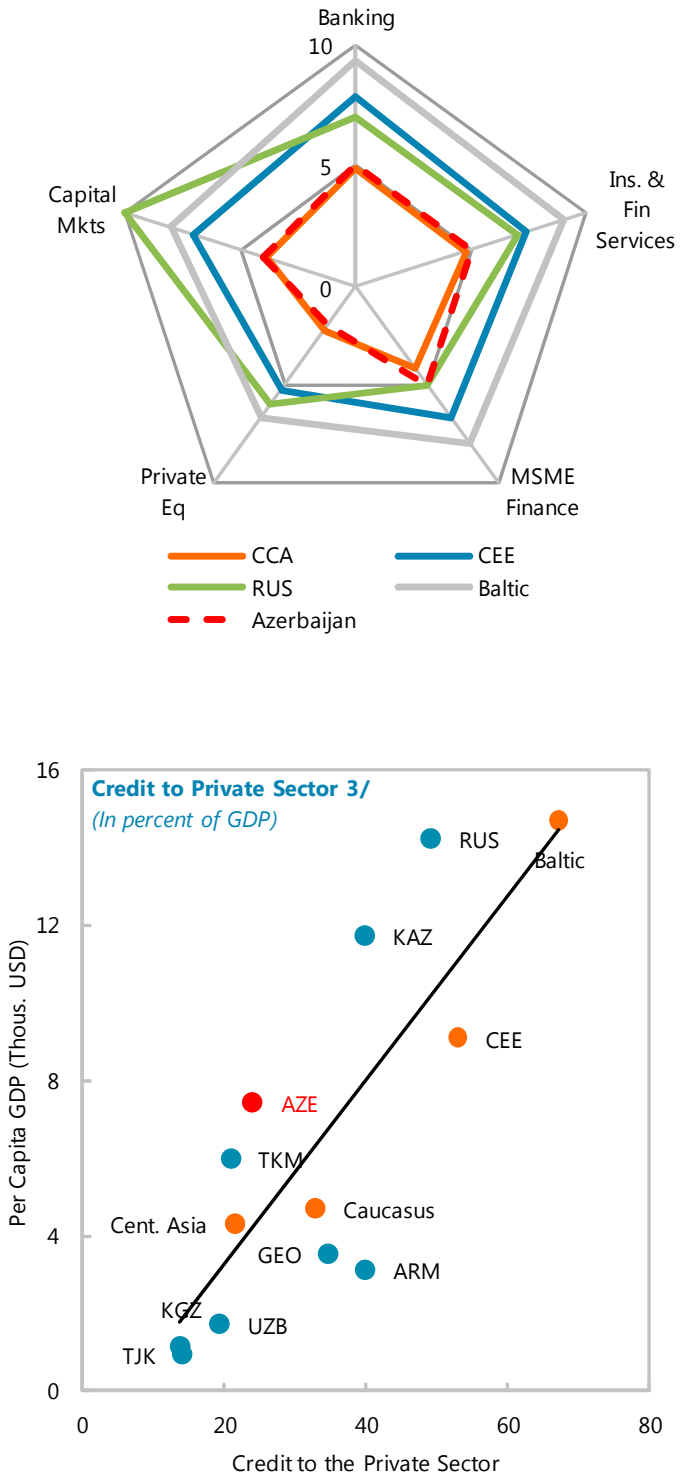

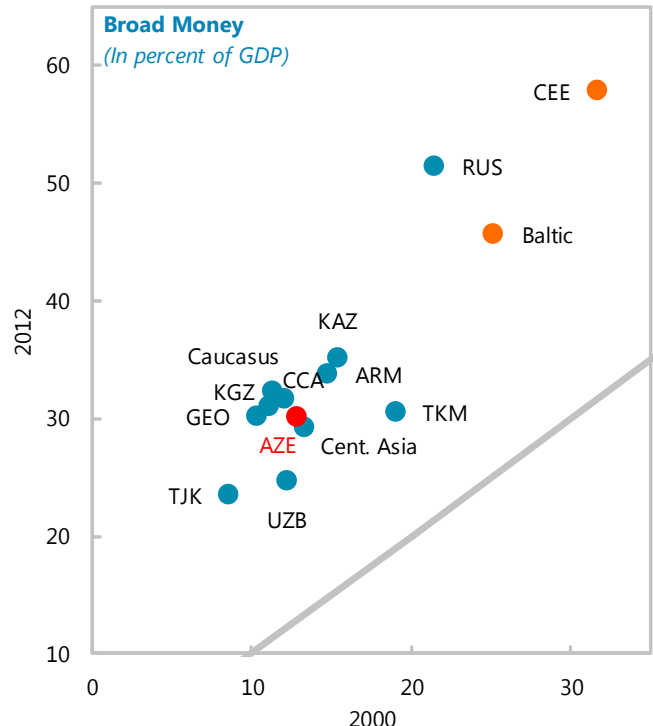

Banking Sector Assets and Foreign Ownership

100

-(In percent of total assets)

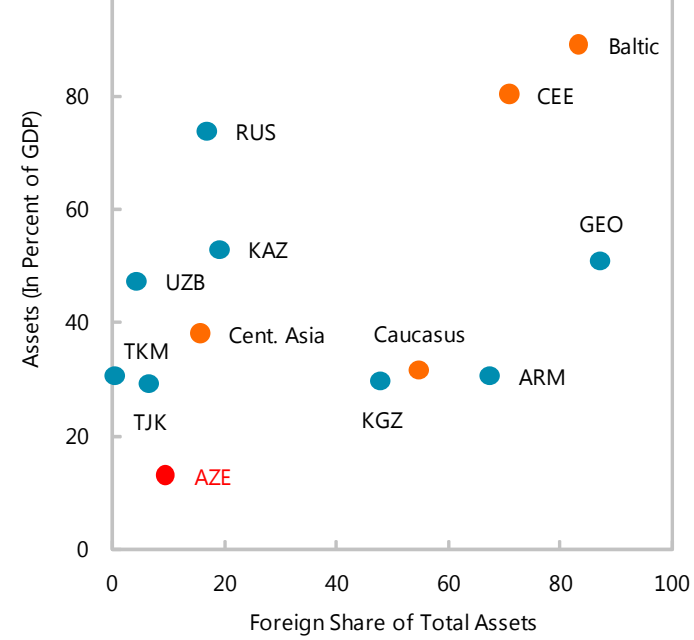

Sources: EBRD; National Authorities; and IMF.

$1 /$ Or latest available.

2/ EBRD methodology. The highest score reflects the standards of an industrialized market economy.

3/ CEE excludes Kosovo. 


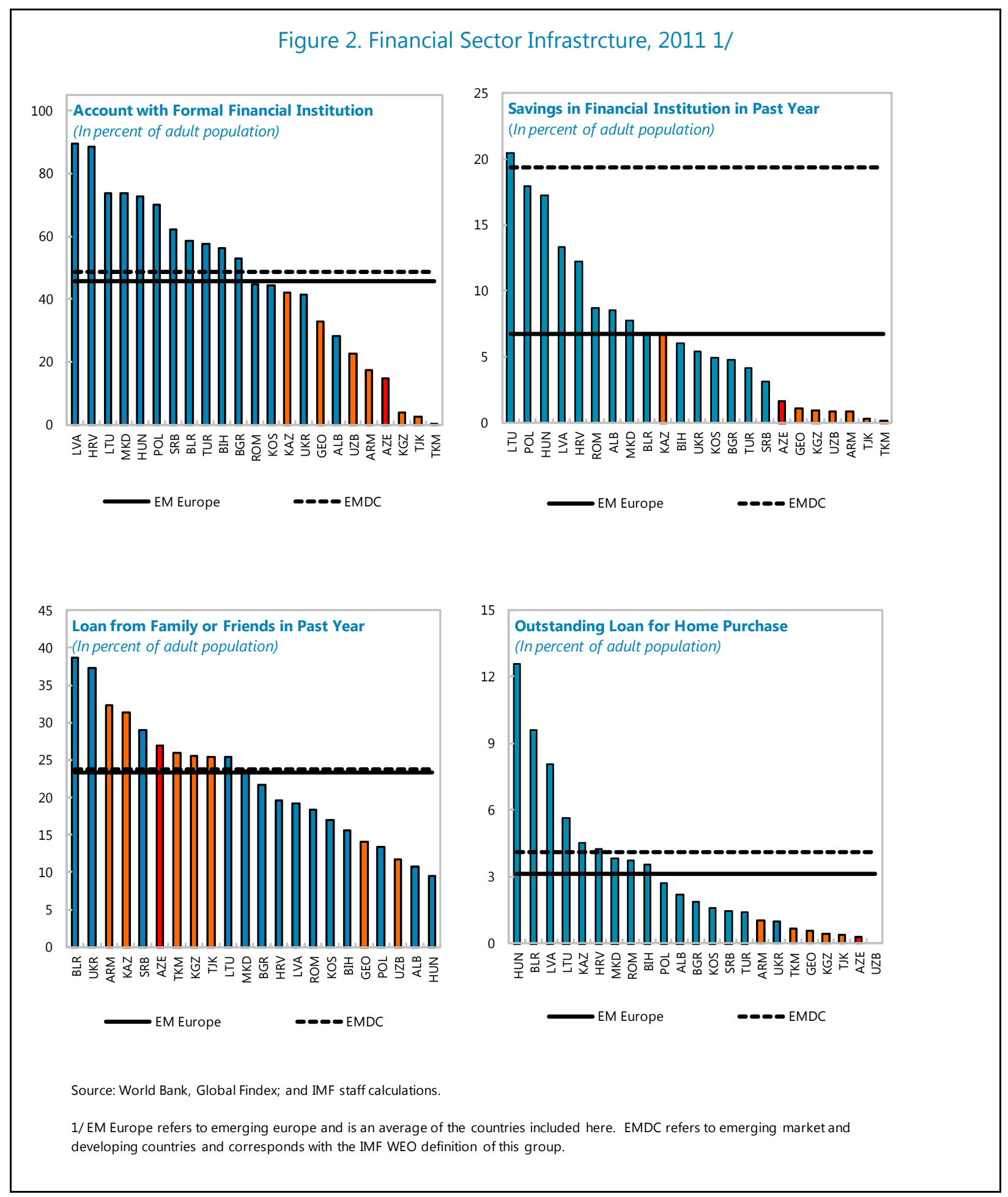


We estimated credit to the private sector as a percentage of GDP in sample of 134 developing and emerging market economies for 1990-2012 with the following specification:

$$
S_{c, t}=\alpha_{1}+\sum \beta_{j} X_{c, t}+\sum \beta_{m} Y_{c, t}+d_{t}+v_{i, t}
$$

where the vector $X_{c, t}$ contains macroeconomic variables for country $c$ at time $t$, namely GDP per capita and inflation taken from the IMF World Economic Outlook database. The vector $Y_{c, t}$ contains country-specific institutional and policy variable that might influence the development of the financial sector. Specifically, our policy and institutional quality variable comprises an index on the rule of law as reported in the World Bank's Worldwide Governance Indicators. ${ }^{10}$ Second, we measure the quality of technical development by including a variable on internet penetration per 1000 population taken from the World Bank's World Development Indicators. The vector $d_{t}$ contains dummy variables that are assigned the value 1 if the sample country is hydrocarbon intensive resource rich developing country (HRDCs). ${ }^{11}$ In order to address heteroscedasticity and estimate the impact of our time invariate HRDCs dummy, a two-step Feasible Generalized Least Squares (FGLS) method is used to estimate the drivers of financial development. ${ }^{12}$ The summary descriptive statistics are found in Table 1 and Table 2 reports various estimations of our model which find the following:

- $\quad$ The coefficients on the macroeconomic variables show that GDP per capita is positively and significantly associated with financial development across all of the five estimated models.

- Our proxy measures of policy and institutional quality ("Rule of Law" and "Internet") are positively correlated and significant at the 0.1 percent level, even when controlling for the level of developed as proxied by GDP per capita. This lends support to our hypothesis that the quality of institutions and the policy environment matter in driving financial development.

Finally, the HRDCs dummy was found to be negative and significant when controlling for income, yet it becomes insignificant when controlling for the quality of policies and institutions. In models 1 and 3, the HRDCs dummy ("RRDC_hydro") is significant at the 0.1 percent level in models comprising the macro variables and internet penetration. Yet, the coefficient on the dummy becomes insignificant when controlling directly for policy quality in models 2 and 5 . These findings confirm

\footnotetext{
10 Table 1 contains summary statistics.

${ }^{11}$ The list of hydrocarbon rich developing countries drawn from IMF, 2012, Macroeconomic Policy Frameworks for Resource-Rich Developing Countries.

12 The analysis builds on the analysis of African economies in Ahokpossi, C., K. Ismail, S. Karmakar, and M. KouletVickot, 2013, "Financial Depth in the WAEMU: Benchmarking Against Frontier SSA Countries," IMF Working Paper WP/13/161.
} 
the prior that HRDCs generally have weaker financial systems than other developing economies, yet being a hydrocarbon-intensive economy does not inevitably lead to low levels of financial development as implementing quality policies and institutions can lead to financial deepening even when controlling for income.

\section{For Azerbaijan and other hydrocarbon intensive exporters, the implication of these} empirical results is that particular attention must be given to policy reform to ensure financial development. The pervasiveness of lower levels of financial development in HRDCs suggests that hydrocarbon wealth may substitute for policy reform. This must be recognized and particular attention given to ensure that public policy supports financial deepening.

\begin{tabular}{|r|rrr|}
\hline \multicolumn{4}{|c|}{ Table 1. Determinants of Credit Growth Summary Statistics } \\
Variable | & Obs & Mean & Std. Dev. \\
Credit to the private sector (o. GDP) & 3199 & 33.29882 & 31.02474 \\
GDP per capita & 3464 & 4357.677 & 8122.462 \\
Inflation & 3048 & 43.90951 & 504.6222 \\
Internet penetration per 1000 pop | & 2924 & 11.20824 & 17.47223 \\
World Bank rule of law indicator & 2612 & -.3446478 & .7875882 \\
-
\end{tabular}

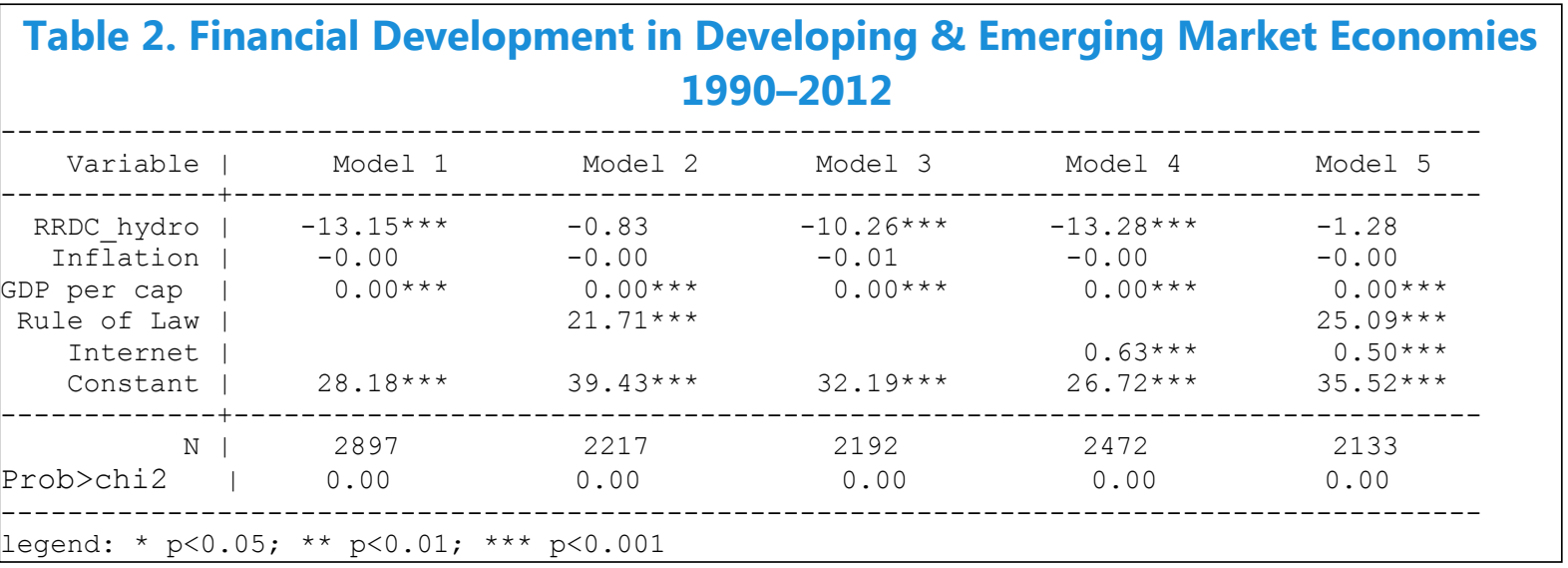




\section{B. Assessing the Relationship between Finance and Growth}

\section{This section investigates the empirical relationship between Azerbaijan's financial} development and the growth of its non-hydrocarbon economy. Though cross-country comparisons illustrate that the Azerbaijan financial sector is relatively underdeveloped, growth in credit to the industry and services increased from just under 5 percent of GDP in 2000 to around 13 percent in 2013 (Fig 3). A large portion of the growth in credit came from growth in household lending which accelerated from around 9 percent of total bank lending in 2000 to around 40 percent in 2013. Mortgages have been an important component of banks' credit to consumers as these comprised about 14 percent of banks' portfolios in 2013, up from 8 percent in 2006, the year in which mortgage lending was reported. The ratio of broad money to GDP exhibits rapid growth in monetization as this ratio grew over 20 percentage points of GDP during 2000-13, with even more rapid growth seen in manat broad money during this period.

\section{Yet what has the impact of these developments been on non-hydrocarbon GDP}

growth? Has the growth of the financial sector helped lift non-oil growth and support the authorities' diversifications objectives? Previous research has suggested that there may be a finance channel for the resource curse in the sense that oil dependent economies benefit less from financial deepening than economies without hydrocarbon resources. ${ }^{13}$

\section{Given the complexities of estimating the empirical relationship between financial} development and economic growth, a number of econometric tools were employed. As Cevik and Rahmati (2013) note, estimating these effects are difficult due to simultaneity as high growth economies may have lower resource constraints and more credit available or there may be higher demand for credit. ${ }^{14}$ In these cases, credit would be endogenous to rapid growth in the economy and may not be driving growth, particularly in the non-resource sectors.

\footnotetext{
${ }^{13}$ Nili, M. and M. Rastad, 2007, "Addressing the Growth Failure of the Oil Economies: The Role of Financial Development," The Quarterly Journal of Economics and Finance, 46, 726-40. Barajas, A., R. Chami, and S.R. Yousefi, 2013, "The Finance and Growth Nexus Re-Examined: Do All Countries Benefit Equally?," IMF Working Paper 13/130.

${ }^{14}$ Cevik, S. and M. Rahmati, 2013, "Searching for the Finance-Growth Nexus in Libya," IMF Working Paper, WP/13/92.
} 


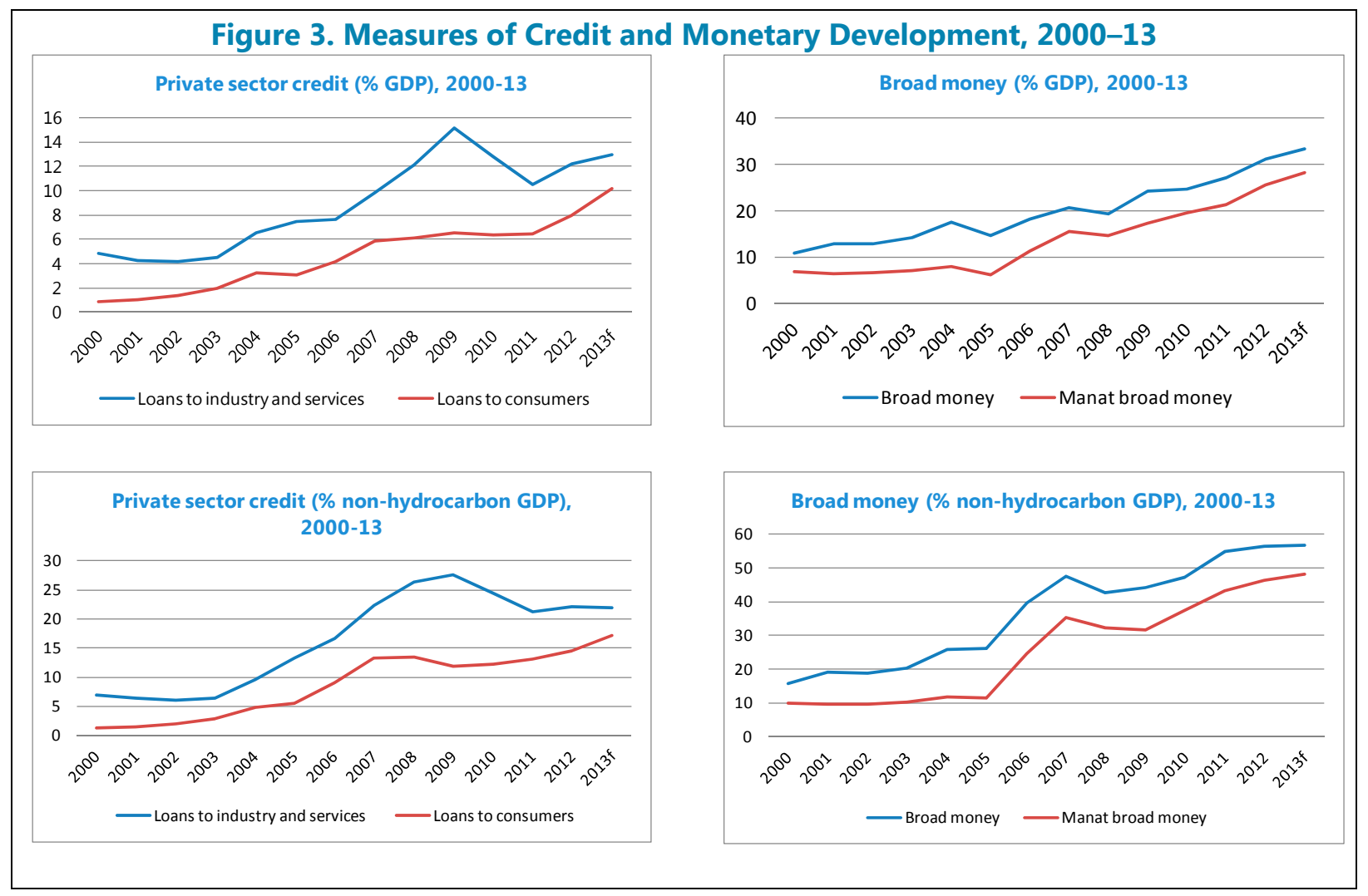

Note: "Loans to industry and services" comprise banking credit extended to the following sectors: (i) trade and services, (ii) power, engineering, chemical and natural resources, (iii) agriculture and processing, (iv) construction and real estate, (v) industry and manufacturing, (vi) transport and communications.

Source: Central Bank of Azerbaijan; IMF staff estimates.

Like Cevik and Rahmati, we follow a three step procedure in exploring the relationship between financial development and non-hydrocarbon growth. The general empirical specification of the relationships that we test are in the following form:

$$
\Delta y_{t}=\alpha+\beta F D_{t}+\gamma X_{t}+\varepsilon_{t}
$$

where $\Delta y_{t}$ is the rate of non-hydrocarbon GDP per capita growth at time $t, F D_{t}$ is the ratio of credit to the private sector to non-hydrocarbon GDP, and $X_{t}$ is a vector of other drivers of nonhydrocarbon growth: the real change in the price of crude oil and the growth rate of real government spending per capita. The data on GDP per capita growth, credit to the private

sector, and public spending are from the Azerbaijani authorities while oil price data are obtained from the IMF's World Economic Outlook database. Using these variables, we conduct the following analyses: (a) test the short-run relationships among these variables through the estimation of simple 
OLS regressions; (b) test whether non-hydrocarbon growth and private sector credit exhibit a longrun relationship and are cointegrated; (c) explore the linear interdependencies among our variables with a vector auto-regression estimates.

10. As a first step in assessing the relationship between finance and growth, an assessment of the properties of our time series finds no evidence of nonstationarity. The empirical test uses quarterly data during 2003-12. The relatively short series reflects data limitations, particularly disaggregated data on bank lending which is only available from 2003. The ADF results, which control for trend effects, find that our measures of credit to the private sector and nonhydrocarbon GDP growth are stationary. ${ }^{15}$

\section{Turning to the empirical test, the results suggest that there is no statistically} significant relationship between non-hydrocarbon growth and private sector credit. The three tests of the drivers of growth in GDP find that public spending is a key driver of growth in the nonhydrocarbon economy, yet growth in credit to the private sector is not found to have a long-run impact. Specifically we find:

- Estimations of the model in OLS find that there is no short-run relationship between financial development and growth. Table 4 presents simple bivariate and multivariate correlations estimated with OLS. The model where credit to the private sector is a regressor (Models 2, 4, and 6) find that the coefficient on "Credit" is not statistically significant, including in a bivariate regression as presented in Model 2. However, real government spending per capita is positively correlated with non-hydrocarbon growth with a coefficient magnitude near 0.30 and is statistically significant at the 1 percent threshold across all specifications where it is a regressor (Models 3, 5, and 6).

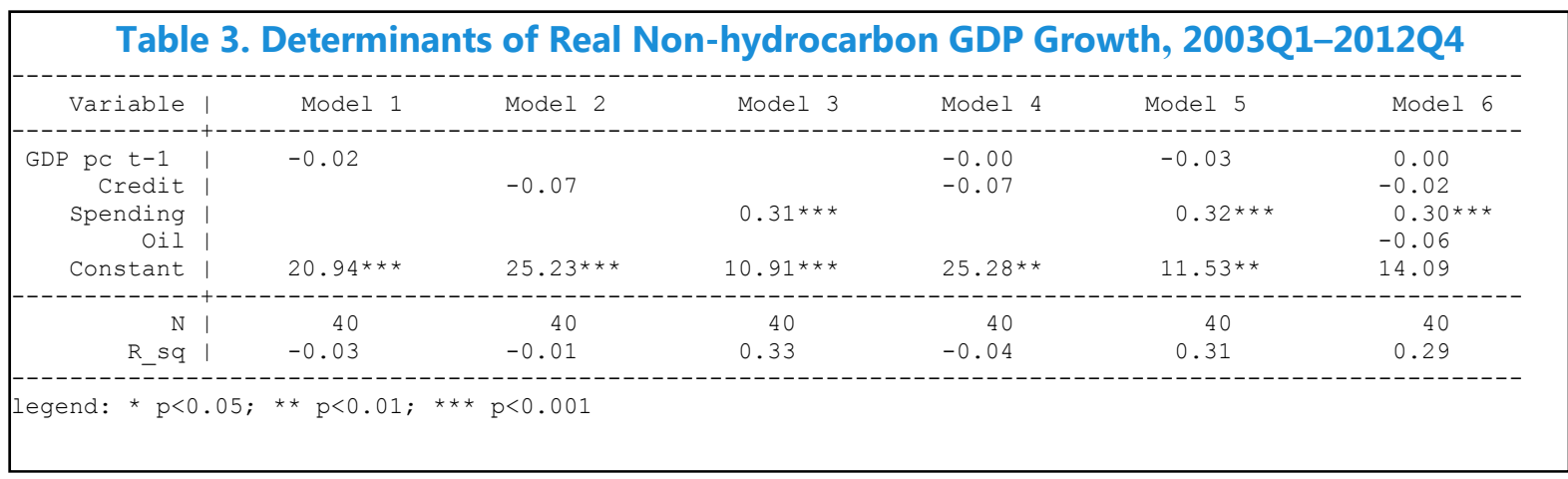

- The test for cointegration through a Johansen procedure provides evidence that there is also not a long-run relationship between financial development and non-

\footnotetext{
${ }^{15}$ Table 3 contains summary statistics.
} 
hydrocarbon growth. The Johansen test provides a system of maximum likelihood estimators to testing for cointegration. ${ }^{16}$ The results, presented in Table 5, is based on four lags and directly tests whether non-hydrocarbon growth is related to a change in the ratio of private sector credit to non-hydrocarbon GDP. The results suggest that there is no statistically valid long-term association between these variables.

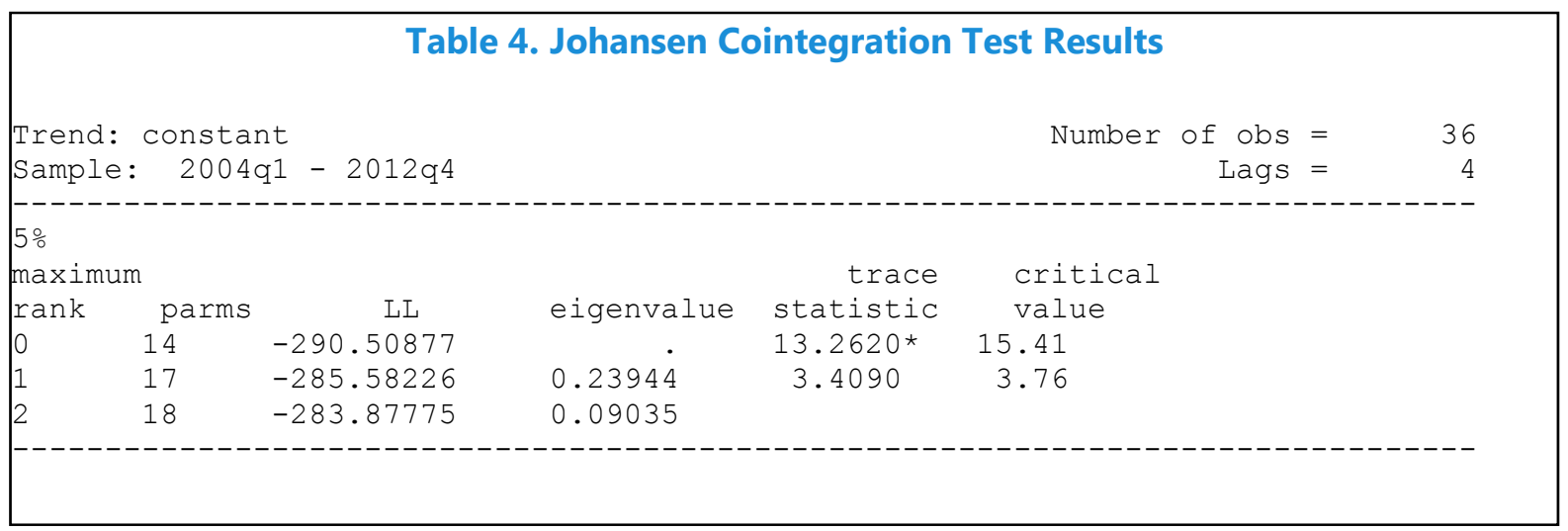

Finally, the vector auto-regression (VAR) estimates also do not support an association between credit and growth. The VAR estimations give us a third and final cut at analyzing these relationships by permitting a direct assessment of the linear interdependencies among the variables in our model without requiring structural assumptions and restrictions. The results further confirm that there is not an empirical relationship between bank credit and non-hydrocarbon growth (Table 6). The coefficients for credit to the private sector in first and second lags in all three models are not significant. However, real government spending is positive and significant at the 0.01 percent level in the model where we include as a regressor in Model 3. This suggests that non-hydrocarbon output has been driven heavily by public spending rather than credit extended by the private sector during our sample time period.

\footnotetext{
16 Johansen, S., 1991, "Estimation and Hypothesis Testing of Cointegration Vectors in Gaussian Vector Autoregressive Models," Econometrica, 59, 6, 1551-80.
} 


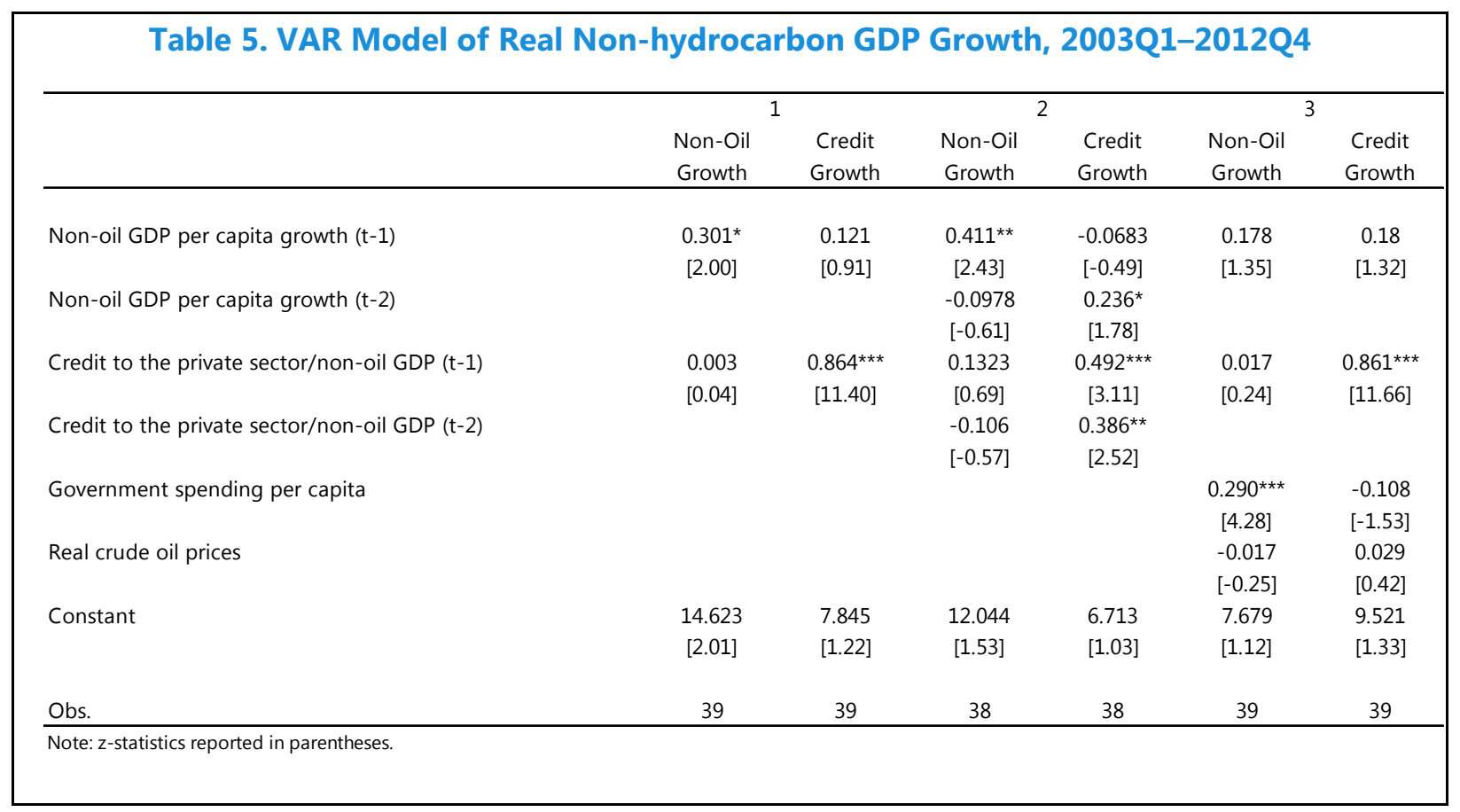

\section{Conclusion}

\section{The composite results from the analyses conducted here suggest that the Azerbaijan} financial sector is not empirically correlated to the development of the non-oil economy. Benchmarking Azerbaijan's levels of financial development against comparator transition economies in Europe and Central Asia found that financial development is relatively weak, even relative to countries with lower levels of per capita income. Previous research suggests that this is not unusual for hydrocarbon-rich developing countries. This paper provides some evidence that a key source of limited financial development may be weak structural policies. The weakening of the hydrocarbonrich country dummy when controlling for a proxy of structural policy quality in our model on the determinants of financial development suggests that improving structural policy (eg, improving the business climate and implementing sound policies of prudential financial oversight) will contribute to financial development regardless of the hydrocarbon intensity of exports. One study on the impact of financial development on growth in Libya, another oil-exporting economy, also found no empirical relationship between financial development and growth and suggested that this may reflect the lack of adequate lending opportunities and bankable projects in the private, enterprise sector or, as our results suggest, may also reflect deficiencies in the policy environment. ${ }^{17}$ Exploring these issues in detail in Azerbaijan will be a useful avenue for future research.

\footnotetext{
${ }^{17}$ Cevik, S. and M. Rahmati, 2013, "Searching for the Finance-Growth Nexus in Libya," IMF Working Paper, WP/13/92.
} 